\title{
Does trace element composition of bivalve shells record utra-high frequency environmental variations?
}

\author{
Poitevin Pierre ${ }^{1,2,{ }^{*}}$, Chauvaud Laurent ${ }^{6}$, Pecheyran Christophe ${ }^{3}$, Lazure Pascal ${ }^{4}$, Jolivet Aurélie ${ }^{5}$, \\ Thebault Julien ${ }^{1}$
}

1 Univ. Brest, CNRS, IRD, Ifremer, LEMAR, F-29280, Plouzané, France

2 Fisheries and Oceans Canada, Maurice Lamontagne Institute, Mont-Joli, QC, Canada

${ }^{3}$ Laboratoire de Chimie Analytique Bio-inorganique et Environnement, Institut Pluridisciplinaire de

Recherche sur L'Environnement et Les Matériaux, CNRS, UMR 5254, Université de Pau et des Pays de

L'Adour, Pau, France

${ }^{4}$ Univ. Brest, CNRS, IRD, UBO, Ifremer, LOPS, F-29280, Plouzané, France

5 TBM Environnement/Somme, 2 Rue de Suéde, 56400, Auray, France

6 Univ. Brest, CNRS, IRD, Ifremer, LEMAR, F-29280, Plouzané, France

* Corresponding author : Pierre Poitevin, email address : poitevin.pierre@gmail.com

laurent.chauvaud@univ-brest.fr ; christophe.pecheyran@univ-pau.fr ; pascal.lazure@ifremer.fr ; a.jolivet@tbm-environnement.com ; julien.thebault@univ-brest.fr

\begin{abstract}
:
Saint-Pierre and Miquelon (SPM) is a small archipelago where instrumental measures based on water column velocity and temperature profiles compiled comprehensive evidence for strong near-diurnal (25.8h) current and bottom temperature oscillations (up to $11.5^{\circ} \mathrm{C}$ ) which is possibly the largest ever observed - at any frequency - on a stratified mid-latitude continental shelf. The main objective of our study was to identify if Placopecten magellanicus can record on its shell these high frequency environmental variations. To this end, we have tried to identify proxies for water temperature and food availability through development of a new ultra-high resolution LA-ICPMS analyses method capable of resolving shell surface elemental composition with a $10 \mu \mathrm{m}$ resolution. This method was applied on two shell fragments, both representing the third year of growth and 2015 annual growth period, respectively coming from two environmentally contrasted sites, more (30 m depth) or less (10 m depth) affected by high frequency thermal oscillations. Our results strongly suggest a relationship between phytoplankton biomass and barium incorporation into P. magellanicus shells at both sites. Even if $P$. magellanicus might present a physiological control of magnesium incorporation, the shape of the two $\mathrm{Mg} / \mathrm{Ca}$ profiles seems to illustrate that temperature also exerts a control on magnesium incorporation in P. magellanicus shells from SPM. While $\mathrm{U} / \mathrm{Ca}$ and $\mathrm{Mg} / \mathrm{Ca}$ profiles show a strong positive correlation for $30 \mathrm{~m}$ site shell, suggesting that uranium incorporation in $\mathrm{P}$. magellanicus shell is at least partially temperature dependent. The absence of such correlation for $10 \mathrm{~m}$ site shell suggests differences in uranium environmental availability or in P. magellanicus biomineralization between these two sites. The resolution of this new analytical method raises questions about such data interpretation related to $P$. magellanicus growth dynamics and physiology or individual scale based environmental measurements.
\end{abstract}




\section{Highlights}

- A new method to resolve shell elemental composition with a $10 \mu \mathrm{m}$ resolution. $\rightarrow \mathrm{Ba} / \mathrm{Ca}$ of Placopecten magellanicus shell seem to be related to phytoplankton dynamic. $\mathrm{Mg} / \mathrm{Ca}$ and $\mathrm{U} / \mathrm{Ca}$ of $P$. magellanicus shell seem partially temperature dependent. This species might also present a physiological control on $\mathrm{Mg}$ and $\mathrm{U}$ incorporation. This method may contribute to a better understanding of ion incorporation in shells.

Keywords : Ultra-high resolution LA-ICPMS, Placopecten magellanicus, shell chemistry, trace elements, environmental change, bivalve, environmental proxies, North Atlantic, Saint-Pierre and Miquelon, Coastal Trapped Wave. 


\section{Introduction}

Saint-Pierre and Miquelon (SPM) is a small archipelago at the confluence of major oceanic currents, marking the boundary between the North Atlantic Ocean subtropical and subpolar gyres. However, SPM archipelago hydrodynamics is poorly known and its physic observations (sensor deployments) only began very recently. In this context, instrumental measurements based on water column velocity and temperature profiles compiled comprehensive evidence for strong near-diurnal $(25.8 \mathrm{~h})$ current and bottom temperature oscillations (up to $11.5^{\circ} \mathrm{C}$ ) from July to October between 10 and $80 \mathrm{~m}$ depth. This feature is possibly the largest ever observed, at any frequency, on a stratified mid-latitude continental shelf (Lazure et al., 2018). The extremely unstable physical nature of this sub-tidal environment associated with the presence of poikilothermic organisms represents a true ecological paradox, making this site a relevant place to study benthic organism responses to chronic thermal variations.

Biogenic carbonate with recognizable periodic growth bands, such as bivalve molluscs can incorporate minor and trace elements into their shells, in amounts depending on their concentrations in the environment and on the physical and biological properties of the surrounding seawater. However, bivalve shell biomineralization is a complex process, subject to strong physiological and kinetic effects related to metabolism, growth rates, ontogenetic age, shell mineralogy, crystal fabrics and organic matrix (e.g. Carré et al., 2006; Freitas et al., 2008; Freitas et al., 2009; Freitas et al., 2016; Klein et al., 1996; Lazareth et al., 2013; Lorens and Bender, 1977; Schöne et al., 2013; Shirai et al., 2014). Owing to their wide geographic distribution, economic importance, rapid growth rates, and the presence of annual growth lines on their shell, pectinid bivalves (aka. scallops) offer good opportunities to document past environmental conditions (Chauvaud et al., 1998). The occurrence of a clearly visible annual banding pattern on the upper valve of the Atlantic sea scallop, Placopecten magellanicus, and the presence of this species in SPM over a wide bathymetric gradient ( 5 to $80 \mathrm{~m})$, make this species a good candidate to track high-frequency past environmental changes - reflected as variations in the shell geochemical properties - at extremely high temporal resolution.

Spatially-resolved geochemical analysis of biogenic carbonates deposited between two accurately dated growth lines can be performed with a wide set of methods, such as laser 
ablation inductively coupled mass spectrometry (LA-ICPMS), secondary ion mass spectrometry (nanoSIMS) or electron micro probe analyser (EMPA). Because of its potential for rapid and accurate high-resolution in situ trace element analysis at relatively low cost and minimal sample preparation requirements, LA-ICPMS has become a routine analytical tool in a wide area of research applications (Warter and Müller, 2017).

As bivalve growth rates have often been related to environmental variables such as food availability or water temperature (Ballesta-Artero et al., 2017; Butler et al., 2010; Marali and Schöne, 2015; Witbaard et al., 1997) and because of the importance of these two parameters to track environmental and ecological changes, we then understand the interest to track and calibrate elemental proxy records of these two variables. For example, some authors proposed that magnesium to calcium ratios $(\mathrm{Mg} / \mathrm{Ca})$ can be used to record water temperature (Ullmann et al., 2013, Bougeois et al., 2014), while there are many reports of strong vital effects in bivalve shells for this element (Lorrain et al., 2005, Wanamaker et al., 2008, Surge and Lohmann, 2008). Uranium-to-calcium ratio has also been suggested as a proxy for temperature in shallow-water corals (Min et al., 1995; Shen and Dunbar, 1995) and in planktonic foraminiferal carbonates (Yu et al., 2008). Some authors also found a pH effect on U/Ca ratios in both inorganic aragonite and calcite (Kitano and Oomori, 1971; Chung and Swart, 1990). Indeed, U/Ca ratios in calcium carbonate are negatively correlated with $\mathrm{pH}$ and $\left[\mathrm{CO}_{3}{ }^{2-}\right]$, because in aqueous solutions the carbonate ion complexes with the uranyl ion $\left(\mathrm{UO}_{2}{ }^{2+}\right)$ at higher $\mathrm{pH}$ (Langmuir, 1978), therefore less uranium is available to be incorporated in shell carbonate. Regarding U/Ca ratio on mollusc shells, Frieder et al. (2014) demonstrated that $\mathrm{U} / \mathrm{Ca}$ varies as a function of $\mathrm{pH}$ in shells of living larvae in Mytilus californianus and Mytilus galloprovincialis. More recently, Zhao et al. (2018) demonstrated by measuring $\mathrm{U} / \mathrm{Ca}$ ratio on $\mathrm{Mya}$ arenaria shells exposed to $p \mathrm{CO}_{2}$-enriched environments the existence of efficient regulatory mechanisms to tightly control the $\mathrm{pH}$ at the site of calcification of this species. . Ba/Ca profiles in bivalve shells are typically characterized by a flat background signal interrupted by sharp peaks. Background level has been suggested to be linked with salinity (Gillikin et al., 2006, 2008). As for peaks, many authors suggested a synchronization with phytoplankton blooms (e.g. Elliot et al., 2009; Lazareth et al., 2003; Stecher et al., 1996; Thébault et al., 2009; Vander Putten et al., 2000). Building on the work of Stecher and Kogut (1999), Thébault et al. (2009) proposed two main hypotheses to 
121 explain the peaks: (1) ingestion of barite originating from assemblages of recently dead

122 diatoms or (2) adsorption of barium onto iron oxyhydroxides associated with diatoms

123 frustules.

124 The main objective of our study was to identify whether the calcitic shell of $P$. magellanicus can record the high frequency $(25.8 \mathrm{~h})$ environmental variations observed in SPM. To this end, we have developed a new ultra-high resolution LA-ICPMS analytical method in order to investigate skeletal trace element concentration with a $10 \mu \mathrm{m}$ resolution. Results of our investigation can contribute to a better understanding of environmental and physiological mechanisms associated to sub daily environmental variations on ions incorporation into fast growing marine bivalve shells.

\section{Materials and Methods}

\subsection{Sample collection}

Two live P. magellanicus were collected in September 2016 from Saint-Pierre Bay (Saint-Pierre and Miquelon - NW Atlantic) respectively at $10 \mathrm{~m}$ and $30 \mathrm{~m}$ depth (Figure 1). Both individuals were in their fourth year of growth. The deepest location consisted in a homogeneous substrate, made of compacted and stable fine sand. At the shallowest one, the substrate was more heterogeneous and consisted of a mixture of gravels, pebbles, and rocks with a seaweed cover. Soft tissues were removed immediately after collection. Both shells were carefully cleaned with freshwater to remove adherent sediment and biological tissues before sample preparation.

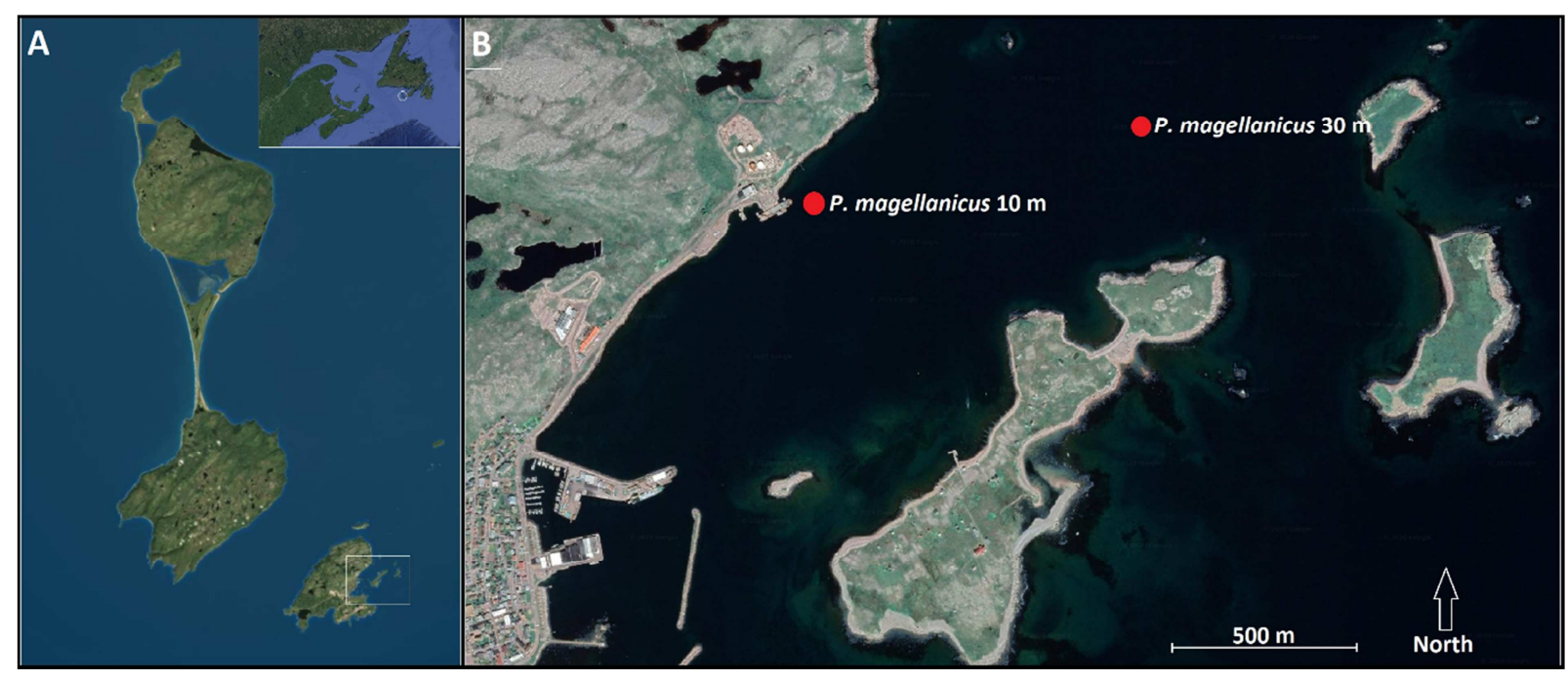


142 Figure 1: (A) Location of Saint-Pierre and Miquelon archipelago. (B) Satellite image of $P$.

143

144

145

146

147

148

149

150

151

152

magellanicus sampling sites (red dots) in Saint-Pierre Bay.

\subsection{Environmental monitoring}

Annual thermal profiles at $10 \mathrm{~m}$ and $30 \mathrm{~m}$ discussed were derived from Lazure et al. (2018) study. To refine our vision of thermal variations on the two collection sites (Figure 1), three multi-parameter probes measuring temperature every 5 minutes were deployed at $8 \mathrm{~m}, 12$ $\mathrm{m}$ and $30 \mathrm{~m}$ depth, between 28/08/2017 and 15/09/2017. The 2015 monthly satellite chlorophyll $a$ measurements were downloaded from the GlobColour website (http://hermes.acri.fr) and are weighted monthly averages of single-sensor products (SeaWiFS/MERIS/MODIS/VIIRSN merged chlorophyll concentrations) over the area 46.6$47.3^{\circ} \mathrm{N} / 56.0-56.6^{\circ} \mathrm{W}$ (i.e., waters surrounding the SPM archipelago within ca. $30 \mathrm{~km}$ ).

\subsection{Sample preparation}

All micro-chemical analyses were performed on P. magellanicus upper valves. Indeed, the lower valves might have been contaminated as a result of a prolonged contact with the sediment. For each individual, a fragment of shell of $c a .3 .5 \mathrm{~cm} \times 1 \mathrm{~cm}$ was cut with a diamond saw, including the axis of maximal growth (Figure 2).

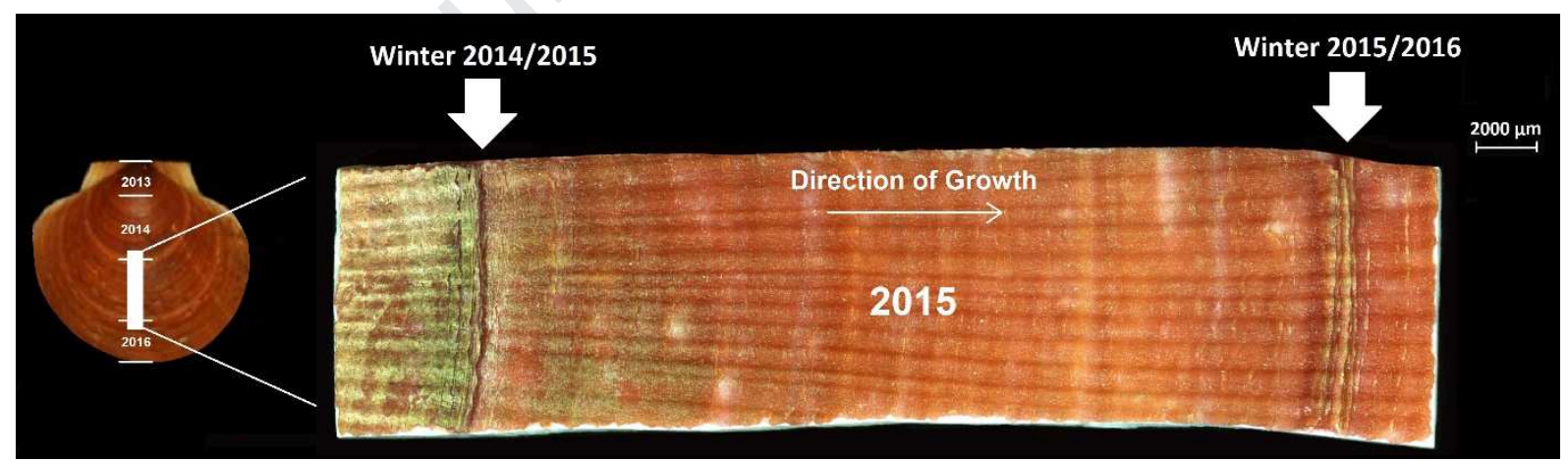

Figure 2: Example of one $P$. magellanicus fragment used for LA-ICPMS analyses. White arrows indicate annual shell growth lines positions defining 2015 increment.

All ultra-high resolution LA-ICPMS analyses were performed one these two shell portions. These fragments represent, for each individual, the third year of growth corresponding to 2015 annual growth periods. The outer shell layer was ultrasonically cleaned with deionized water to remove organic matter and sediment particles. In addition, before LA-ICPMS 


\section{Joumal Pre-proof}

165

analyses, the outer shell layer of each sample was chemically cleaned with a 15 seconds acetic acid (10\%) bath, soaked in deionized water during 10 seconds, and left to air dry in the LA-ICPMS clean room.

\subsection{Ultra-high resolution fs-LA-ICPMS analysis}

A UV high-repetition-rate femtosecond laser ablation (fs-LA) system (Nexeya SA, Canejan, France) was employed (Pulse duration: 360fs; wavelength: $257 \mathrm{~nm}$ ). Each ICPMS measurement point represents an ablation transect with a 1-mm long arcuate trajectory, parallel to the ventral margin, made by fast round trips of a $10 \mu \mathrm{m}$ spot (Figure 3 ). All transects were adjacent in order to analyse the whole "2015 annual period of growth" for the two individuals. The area, covered by a $1 \mathrm{~mm} \times 10 \mu \mathrm{m}$ transect is equivalent to the area covered by a $110 \mu \mathrm{m}$ diameter round spot.

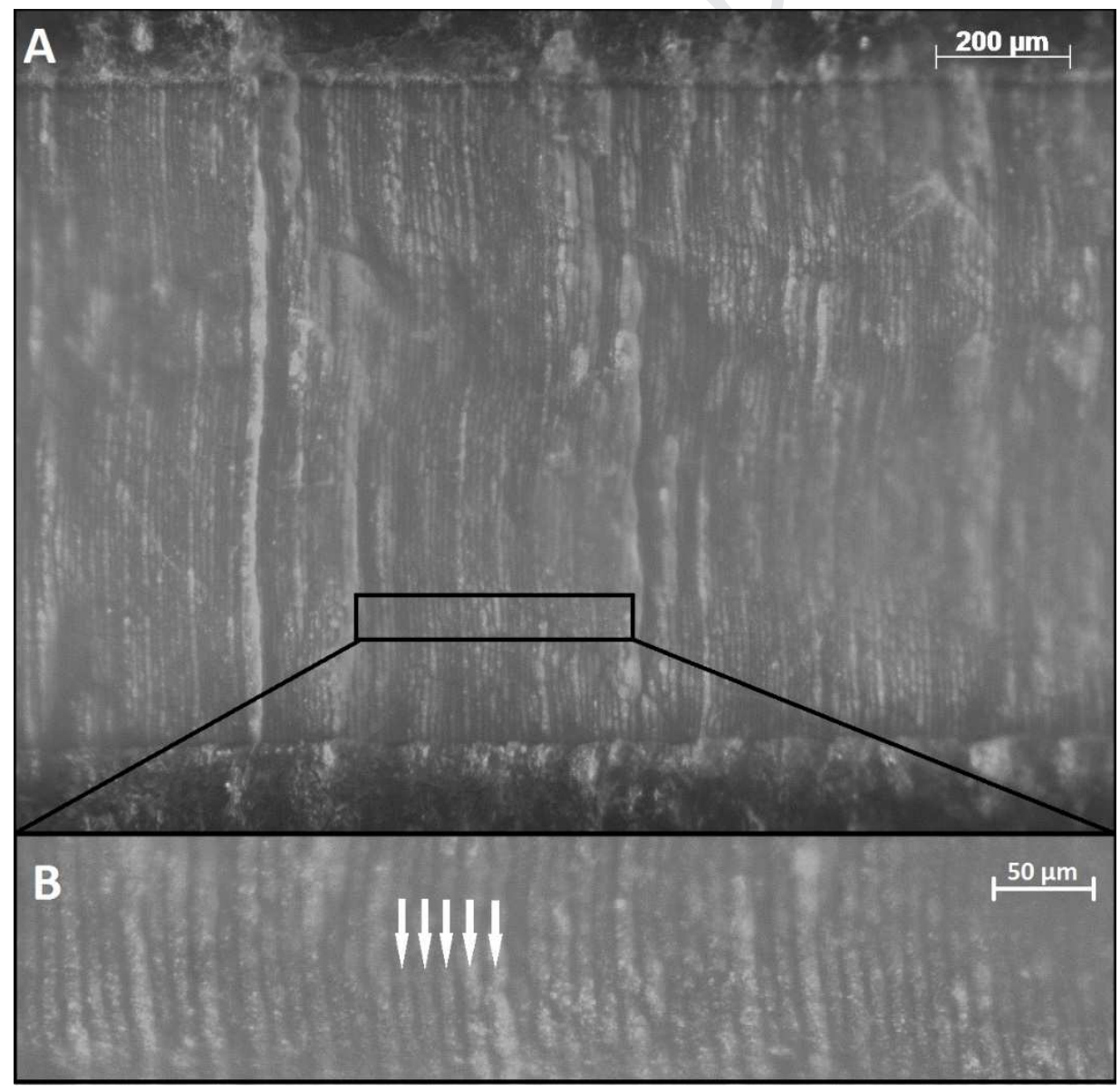

Figure 3: Post ablation picture of a $1.5 \mathrm{~mm} \mathrm{P.} \mathrm{magellanicus} \mathrm{section} \mathrm{showing} \mathrm{ca.} 150$ femtosecond laser ablation transects (A). Zoom on a small fraction of them, each white 
arrow points to a laser ablation transect (B). The visible lines represent ridges generated during the laser ablation process.

Outer shell layers were analysed for $\mathrm{Mg} / \mathrm{Ca}, \mathrm{Ba} / \mathrm{Ca}$ and $\mathrm{U} / \mathrm{Ca}$ ratios using a high-resolution inductively coupled plasma mass spectrometer fitted with a jet interface (Element XR, Thermo Scientific, USA). A helium gas stream carried ablated material to the HR-ICP-MS (carrier gas flow rate $0.68 \mathrm{~L} \cdot \mathrm{min}^{-1}$ ). Elemental ratios were quantified by monitoring ${ }^{43} \mathrm{Ca}$, ${ }^{24} \mathrm{Mg},{ }^{138} \mathrm{Ba}$, and ${ }^{238} \mathrm{U}$. Calcium was used as an internal standard. Elements were standardized to calcium based on the stoichiometry of calcium carbonate (388 $000 \mu \mathrm{gCa} \cdot \mathrm{g}^{-1}$ outer shell layer), assuming $100 \% \mathrm{CaCO}_{3}: \mathrm{Mg} / \mathrm{Ca}\left(\mu \mathrm{g} \cdot \mathrm{g}^{-1}\right), \mathrm{Ba} / \mathrm{Ca}\left(\mu \mathrm{g} \cdot \mathrm{g}^{-1}\right)$ and $\mathrm{U} / \mathrm{Ca}\left(\mu \mathrm{g} \cdot \mathrm{g}^{-1}\right)$. Quantification of trace elements in otoliths was achieved by external calibration using both carbonate pellets FEBS-1 (Barats et al., 2007) and 2 NIST glass standards $(610,612)$ to ensure the best accuracy. Each standard was analysed three times before and after each session with the laser to account for drifting during the day. The limits of detection ( $\mu g . g-1$ in shells) achieved in this study were $0.08,0.01$ and 0.002 for $24 \mathrm{Mg}, 138 \mathrm{Ba}$, and $238 \mathrm{U}$, respectively. They were based on a $3 \sigma$ criterion, where $\sigma$ is the standard deviation of the mean blank count for each isotope. All the elemental concentrations in the outer shell layer were above the detection limits.

\section{3. $\underline{\text { Results }}$}

\subsection{Environmental parameters:}

Around $10 \mathrm{~m}$ depth, the temperature varied from $2{ }^{\circ} \mathrm{C}$ in May to a maximum of $16{ }^{\circ} \mathrm{C}$ in early September and then decreased to $8{ }^{\circ} \mathrm{C}$ in November. At this depth, seawater temperature presents a classic seasonal cycle with cold water intrusions (Figure 4). During the first two weeks of September at $8 \mathrm{~m}$ and $12 \mathrm{~m}$ in Saint-Pierre Bay, temperature showed highfrequency variations with cold water incursions leading to $4^{\circ} \mathrm{C}(8 \mathrm{~m})$ to $6^{\circ} \mathrm{C}(12 \mathrm{~m})$ amplitudes (Figure 4). Along these two weeks, temperatures were $70 \%$ of the time above $12{ }^{\circ} \mathrm{C}$ (Figure 4). 

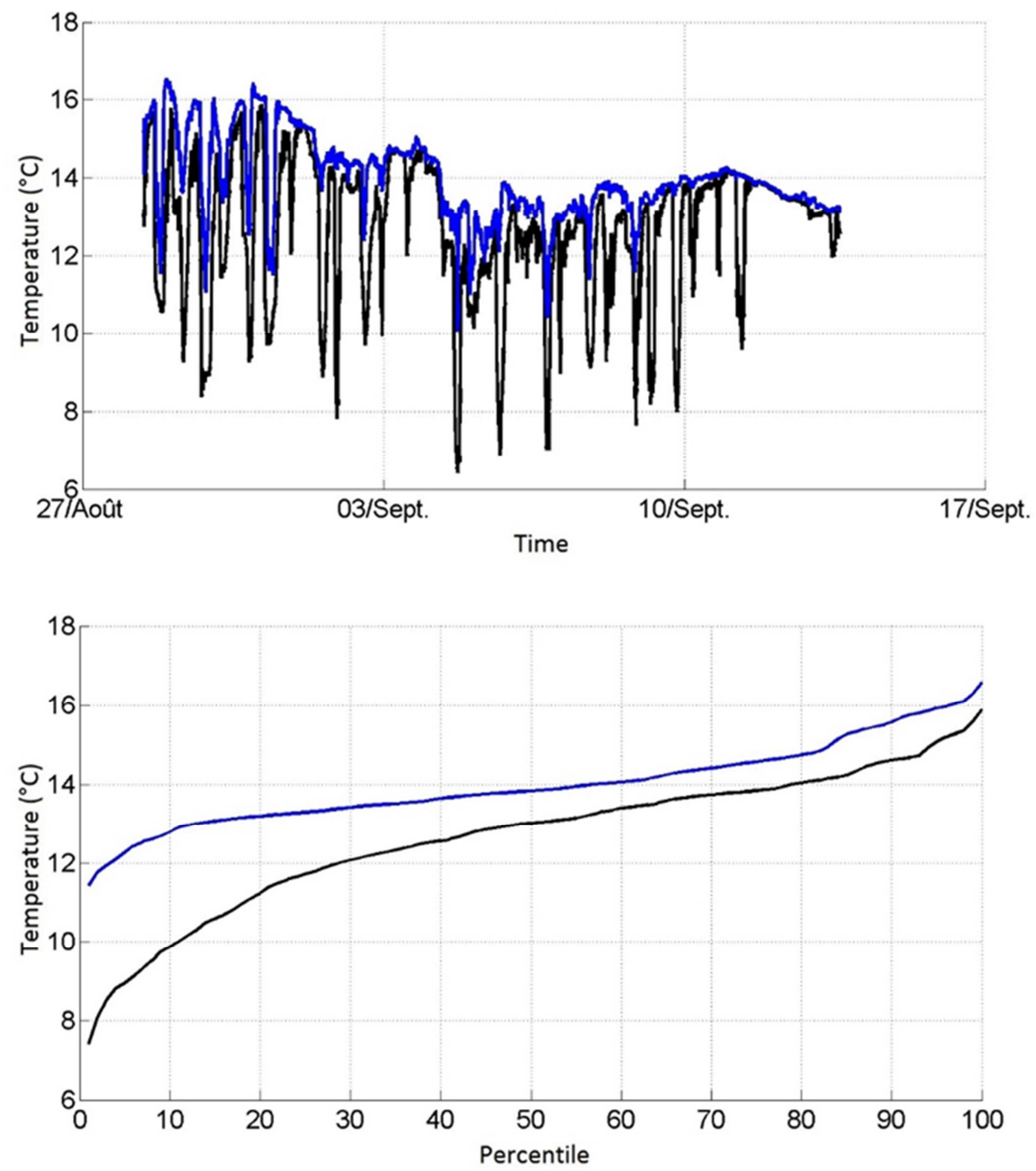

Figure 4: End of August and first two weeks of September 2017 time series of seawater temperatures at $8 \mathrm{~m}$ and $12 \mathrm{~m}$ depth (blue and black) (top graphic). Percentile distribution of these temperatures at $8 \mathrm{~m}$ and $12 \mathrm{~m}$ depth (blue and black).

At $30 \mathrm{~m}$ depth, the temperature annual profile was radically different (Figure 5). Seawater temperature baseline is mainly cold over the year, showing low seasonal amplitudes. However, during the stratified period, temperatures showed high-frequency variations 212 whose amplitude increased with sea-surface temperature. During the first two weeks of 213 September (Figure 5), oscillations were the largest in term of amplitude, reaching nearly $10^{\circ} \mathrm{C}$. Along these two weeks, temperatures were $80 \%$ of the time below $8{ }^{\circ} \mathrm{C}$ (Figure 5). 

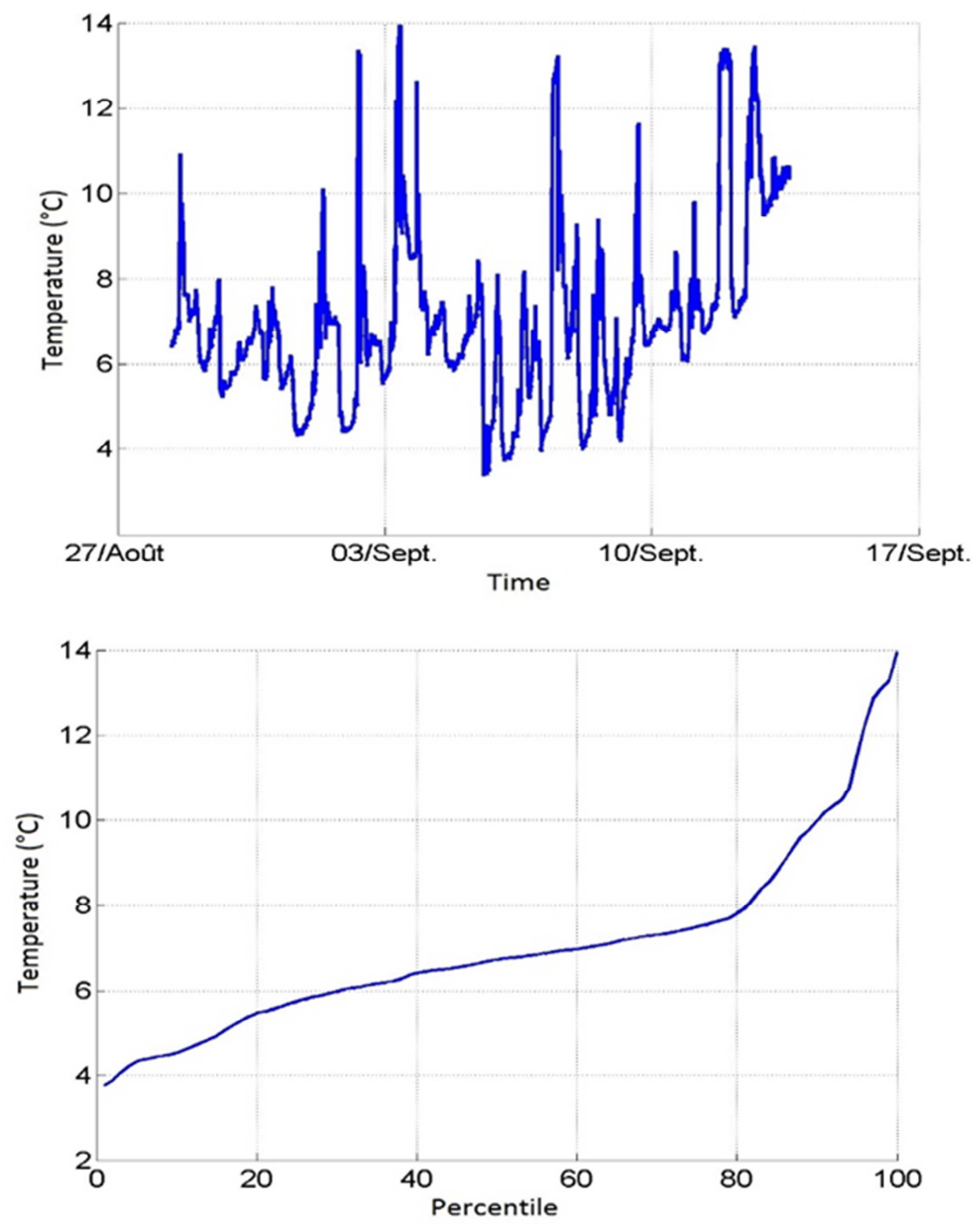

216 Figure 5: End of August and first two weeks of September 2017 time series of seawater 217 temperatures at $30 \mathrm{~m}$ depth (top graphic). Percentile distribution of these temperatures 218 during these two weeks.

219

220 Monthly mean satellite chlorophyll $a$ concentrations ranged from 0.46 to $1.22 \mathrm{mg} \cdot \mathrm{m}^{-3}$ (Figure 221 6). The annual time series-exhibited a background level around $0.7 \mathrm{mg} \cdot \mathrm{m}^{-3}$, with one major 222 peak in April - May 2015. 
Chlorophylle a

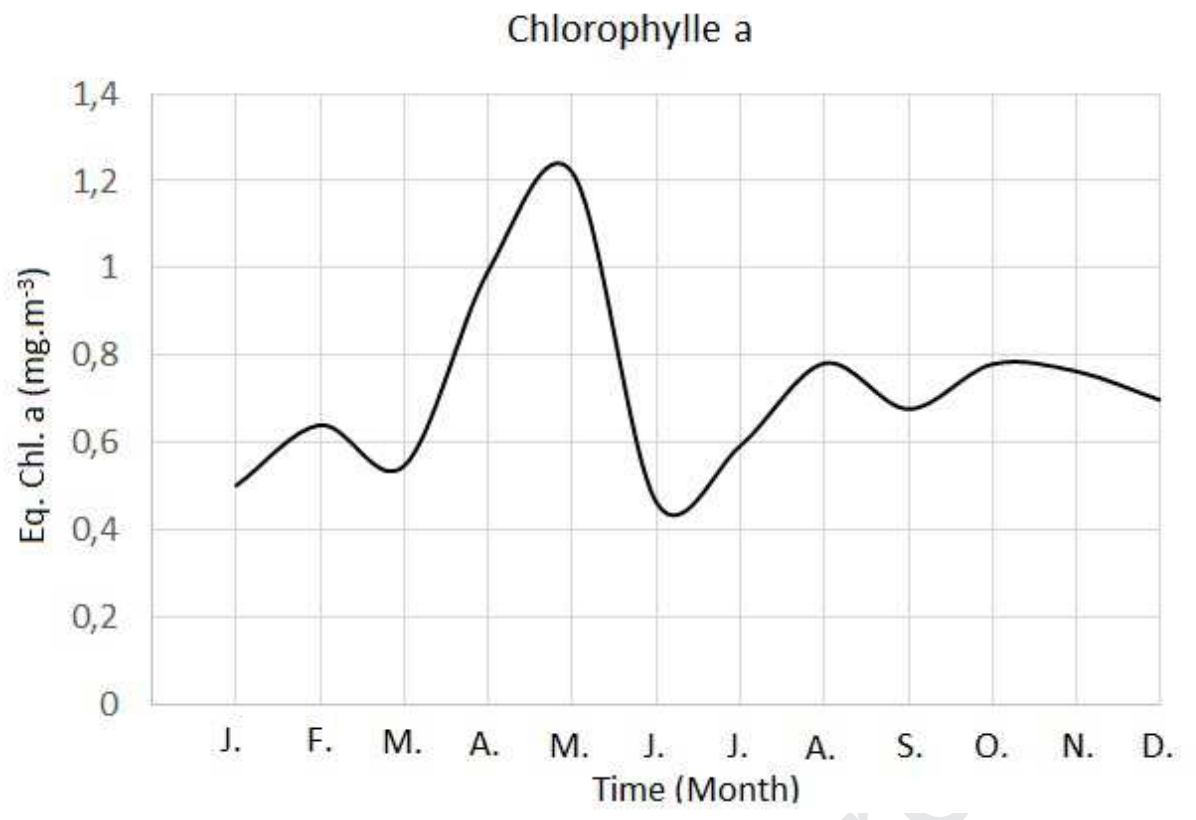

224 Figure 6: Monthly satellite equivalent chlorophyll a $\left(\mathrm{mg} \cdot \mathrm{m}^{-3}\right)$ measurements over the year 2252015.

Outer shell layer $\mathrm{Ba} / \mathrm{Ca}$ ratios ranged from 0.61 to $15.71 \mu \mathrm{g} \cdot \mathrm{g}^{-1}$ at $10 \mathrm{~m}$ and from 0.43 to $12.54 \mu \mathrm{g} \cdot \mathrm{g}^{-1}$ at $30 \mathrm{~m}$ (Figure 7). Both series have the same profile with one major peak occurring respectively $370 \mu \mathrm{m}$ and $830 \mu \mathrm{m}$ after the "winter 2014/2015" growth line. The main $\mathrm{Ba} / \mathrm{Ca}$ peak covers 1370 and $2220 \mu \mathrm{m}$ of shell at 10 and $30 \mathrm{~m}$, respectively. A secondary smaller $\mathrm{Ba} / \mathrm{Ca}$ peak occurred immediately after the first one, covering respectively 2331230 and $1160 \mu \mathrm{m}$ at 10 and $30 \mathrm{~m}$. Ba/Ca baseline was the same for the two time-series 234 (around $1.5 \mu \mathrm{g} \cdot \mathrm{g}^{-1}$ ). 

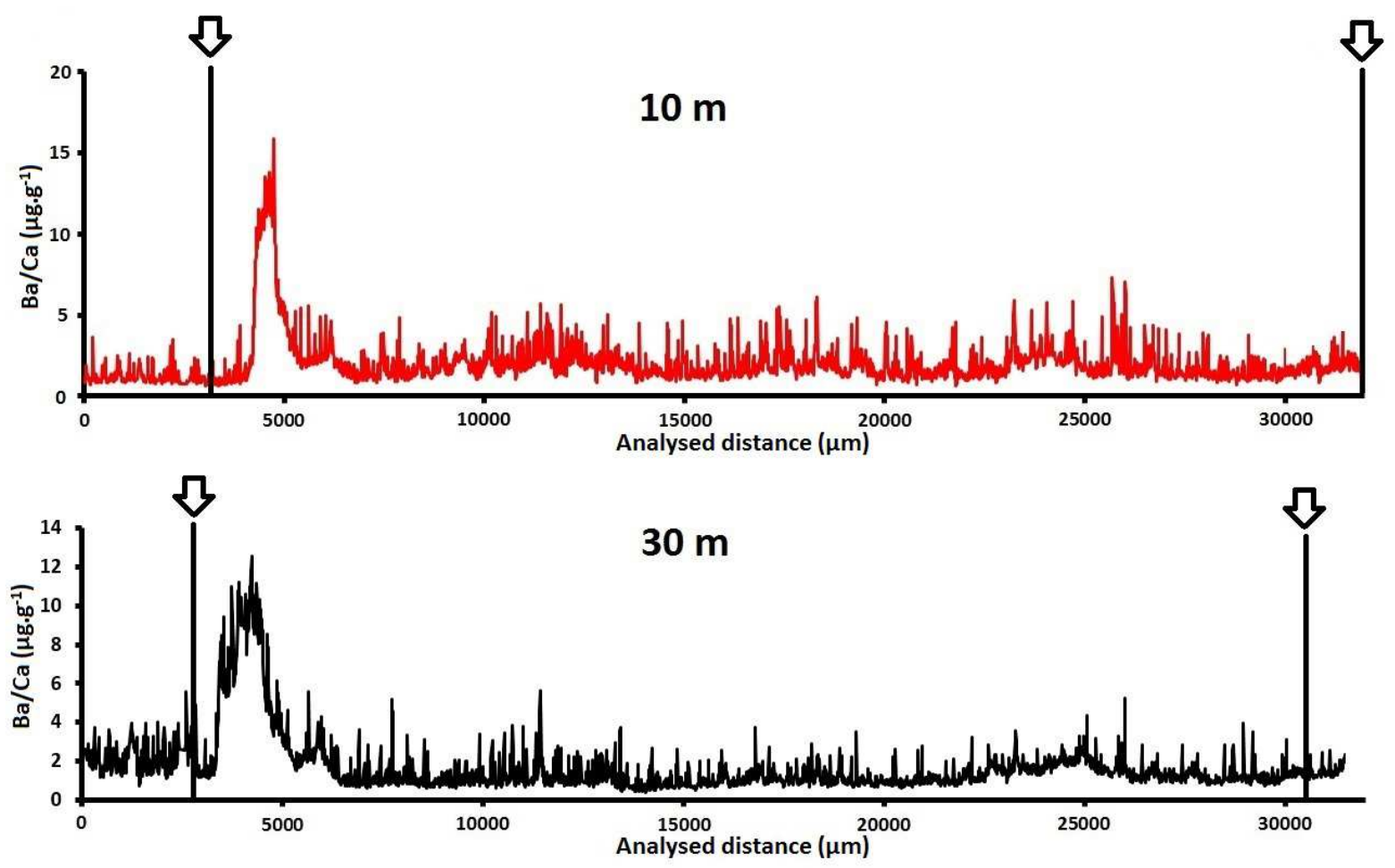

235

236 Figure 7: $\mathrm{Ba} / \mathrm{Ca}\left(\mu \mathrm{g} \cdot \mathrm{g}^{-1}\right)$ series at $10 \mathrm{~m}$ (red curve) and $30 \mathrm{~m}$ (black curve). Vertical lines

237 placed under the arrows indicate the position of winter shell growth lines.

\section{3 $\mathrm{Mg} /$ Ca ratio profiles}

Outer shell layer Mg/Ca ratios ranged from 232 to $1408 \mu \mathrm{g}$.g-1 at $10 \mathrm{~m}$ and from 233 to 1495

$\mu \mathrm{g} \cdot \mathrm{g}^{-1}$ at $30 \mathrm{~m}$ (Figure 8 ). At $10 \mathrm{~m}, \mathrm{Mg} /$ Ca profile followed a sinusoidal pattern with stronger 

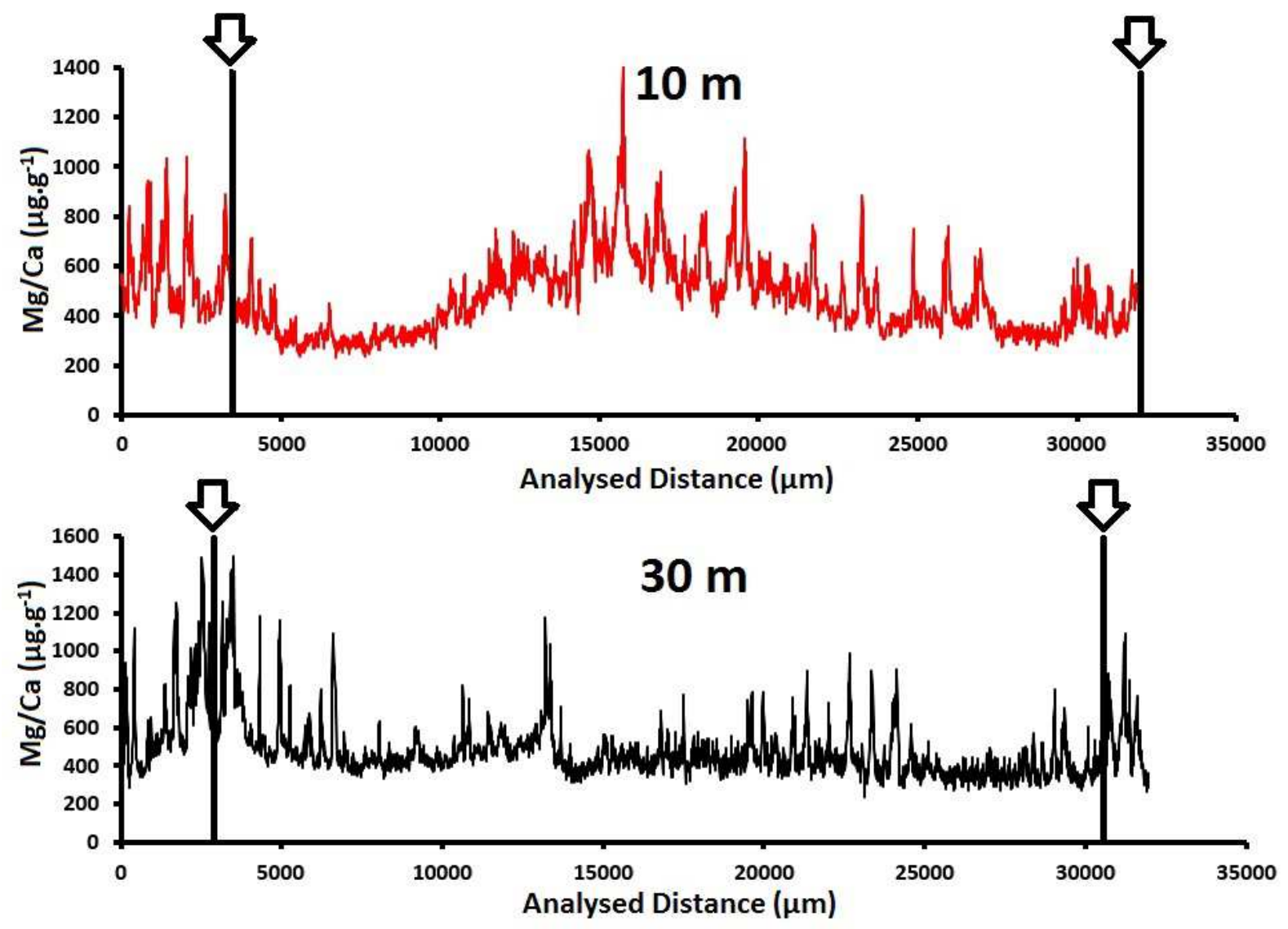

247 Figure $8: \mathrm{Mg} / \mathrm{Ca}\left(\mu \mathrm{g} \cdot \mathrm{g}^{-1}\right)$ series at $10 \mathrm{~m}$ (red curve) and $30 \mathrm{~m}$ (black curve). Vertical lines

248 placed under the arrows indicate the position of shell growth lines.

\section{$3.4 \mathrm{U} / \mathrm{Ca}$ ratio profiles}

251 Outer shell layer U/Ca ratios ranged from 0.003 to $0.16 \mu \mathrm{g} . \mathrm{g}-1$ at $10 \mathrm{~m}$ and from 0.004 to 0.36

$252 \mu g . g-1$ at $30 \mathrm{~m}$ (Figure 9). At $10 \mathrm{~m}$ depth, U/Ca time series had a relatively flat pattern with high-

253 frequency variations all along the profile. At $30 \mathrm{~m}$ depth, U/Ca profile was close to $\mathrm{Mg} / \mathrm{Ca}$ one.

254 So we decided to compare those profiles in the next paragraph. 

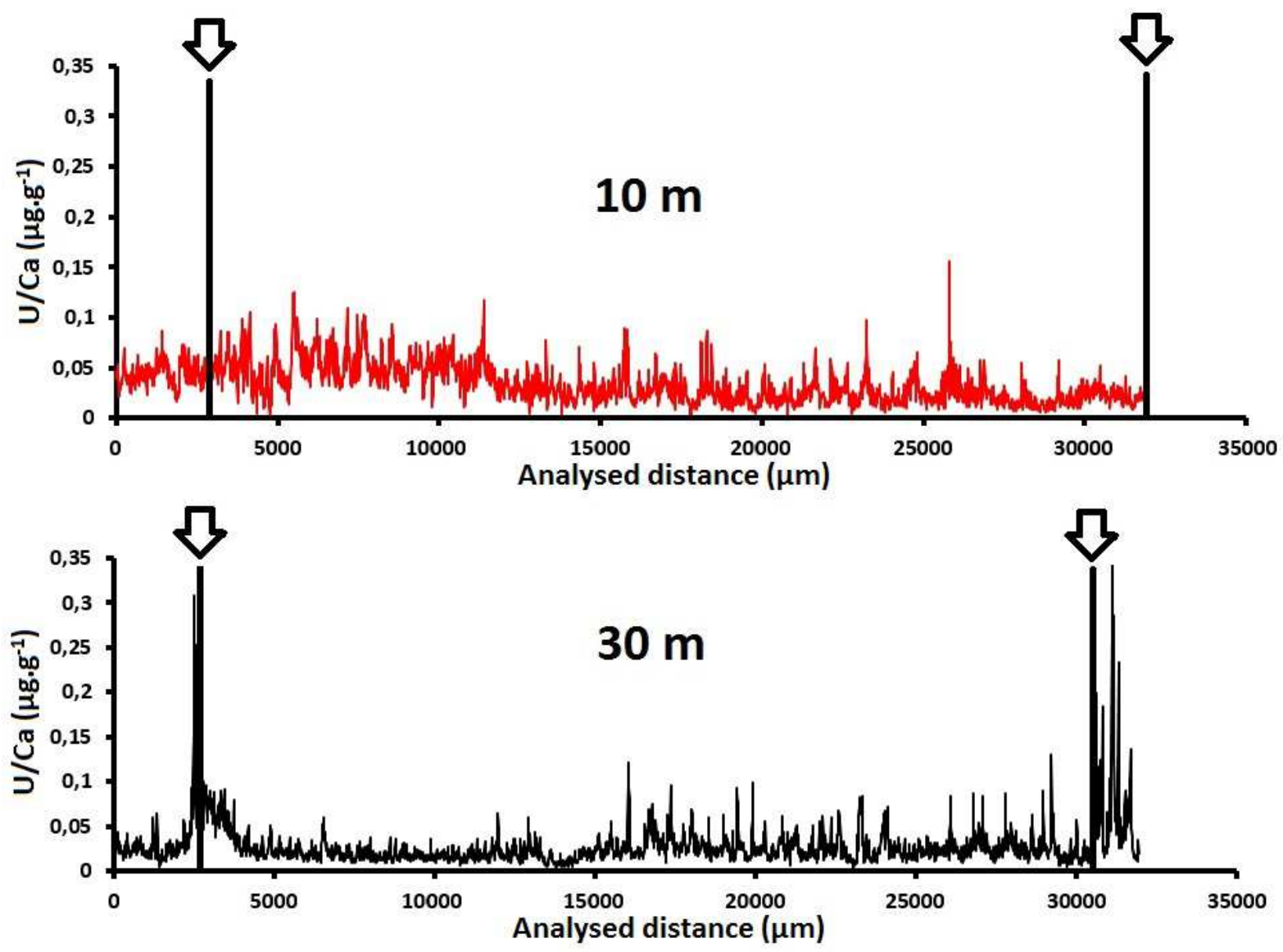

256 Figure 9: $\mathrm{U} / \mathrm{Ca}\left(\mu \mathrm{g} \cdot \mathrm{g}^{-1}\right)$ series at $10 \mathrm{~m}$ (red curve) and $30 \mathrm{~m}$ (black curve). Vertical lines placed 257 under the arrows indicate the position of shell growth lines.

3.5 $\mathrm{U} / \mathrm{Ca}$ and $\mathrm{Mg} / \mathrm{Ca}$ comparison at $30 \mathrm{~m}$ depth:

260 At $30 \mathrm{~m}$ depth, $\mathrm{U} / \mathrm{Ca}$ and $\mathrm{Mg} / \mathrm{Ca}$ profiles presented a strong positive correlation $(\mathrm{N}=3135, \mathrm{r}$ $261=0.62, p<0.001$ ) (Figure 10). A closer examination of this relationship on a shorter time 262 window (i.e. three high frequency cycles, between $22400 \mu \mathrm{m}$ and $24250 \mu \mathrm{m}$ ) revealed an even stronger correlation $(\mathrm{N}=186, \mathrm{r}=0.77, p<0.001)$. 

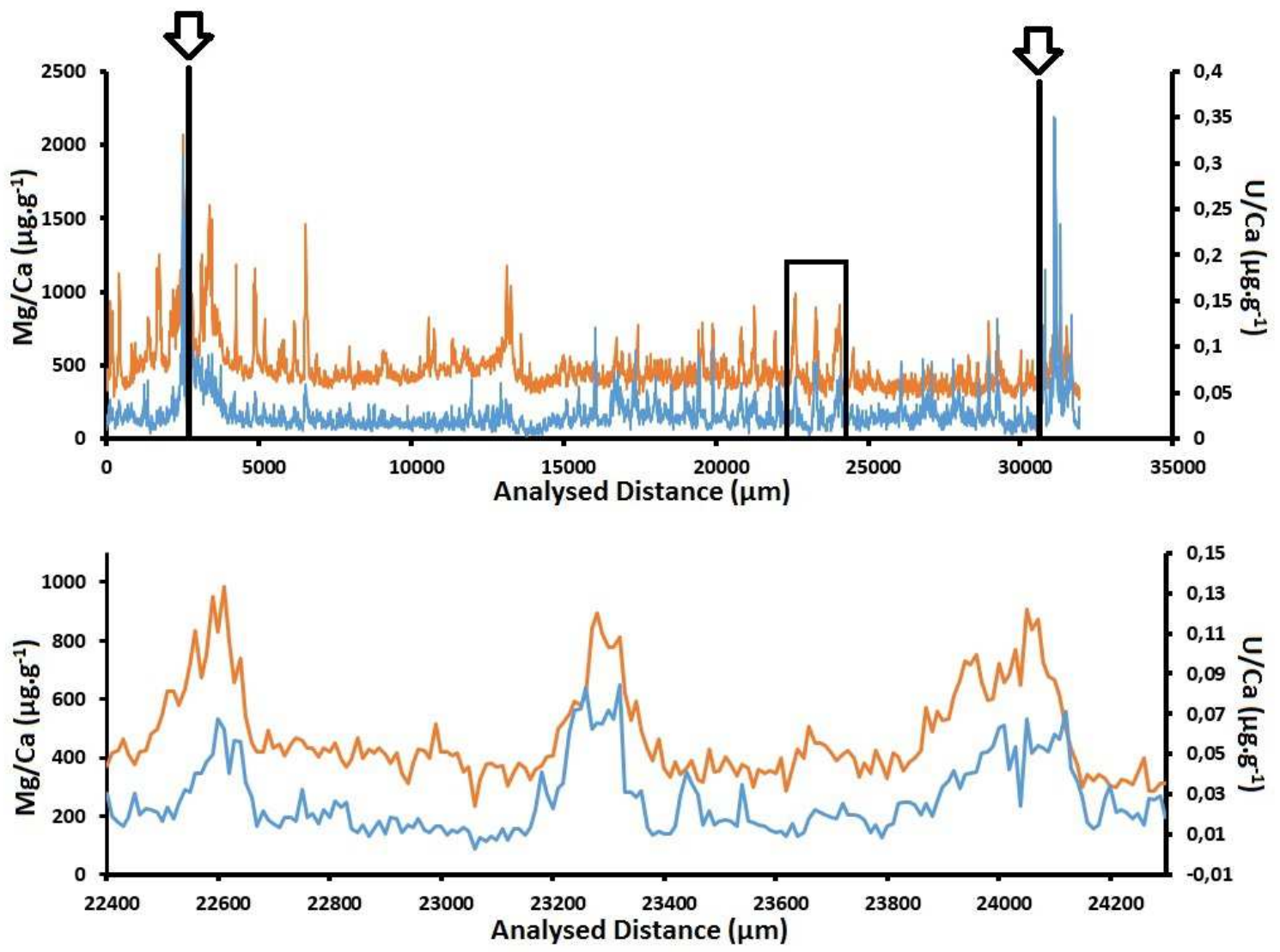

Figure 10: $\mathrm{U} / \mathrm{Ca}\left(\mu \mathrm{g} \cdot \mathrm{g}^{-1}\right.$ ) (blue curve) and $\mathrm{Mg} / \mathrm{Ca}\left(\mu \mathrm{g} \cdot \mathrm{g}^{-1}\right.$ ) (orange curve) series at $30 \mathrm{~m}$. Vertical lines placed under the arrows indicate the position of shell growth lines. The graph bellow represents a close-up on three peaks (black box in the upper graph).

\section{Discussion}

This paper presents the first chemical analyses performed on $P$. magellanicus shells. Regarding the temporal resolution $(25.82 \mathrm{~h}$ ) of the environmental phenomena we wanted to track, it was necessary to develop a new analytical method. Our novel approach using ultrahigh resolution fs-LA-ICPMS enables trace element analyses in bivalve shells with a $10-\mu \mathrm{m}$ resolution. This study gave us first insights about $P$. magellanicus ability to record highfrequency environmental variations within is shell.

\subsection{Barium}

277 The high degree of similarity between the two Ba/Ca profiles suggests that the occurrence of $\mathrm{Ba} / \mathrm{Ca}$ peaks was controlled by one or multiple common environmental factors. The pattern 
of these two $\mathrm{Ba} / \mathrm{Ca}$ profiles is similar to those observed in cross sections of other bivalve species (e.g., Gillikin et al., 2008; Stecher et al. 1996; Vander Putten et al., 2000). This confirms the hypothesis which suggests that the choice of analyzing the shell surface or the outer shell layer in cross sections do not have significant influence on $\mathrm{Ba} / \mathrm{Ca}$ records in shells. In this section, we will discuss several hypotheses to explain temporal variability of $\mathrm{Ba} / \mathrm{Ca}$ in P. magellanicus shell. Background levels of $\mathrm{Ba} / \mathrm{Ca}$ time-series in bivalve shells have been suggested to record salinity variations (e.g. Gillikin et al., 2006). There is generally a linear inverse relationship between seawater salinity and dissolved barium concentrations (Coffey et al., 1997; Gillikin et al., 2006). However, variability in seawater dissolved barium concentrations as a source for the $\mathrm{Ba} / \mathrm{Ca}$ peaks in $P$. magellanicus from SPM is highly unlikely. Indeed, SPM islands, due to their offshore status, are not subjected to major riverine inputs and associated variations in salinity (Poitevin et al., 2018). Salinity usually ranges from 31.3 to 32.2 PSU (see Figure 4 in Poitevin et al., 2018) without a clear seasonal trend and, therefore, cannot explain $\mathrm{Ba} / \mathrm{Ca}$ peaks measured in the shells. Many authors suggested a close relationship between these $\mathrm{Ba} / \mathrm{Ca}$ peaks and phytoplankton blooms (e.g. Elliot et al., 2009; Lazareth et al., 2003; Stecher et al., 1996; Thébault et al., 2009; Vander Putten et al., 2000). In our study, the high similarity of chlorophyll a concentration (Figure 6) and $\mathrm{Ba} / \mathrm{Ca}$ (Figure 7) profiles strongly suggest a relationship between phytoplankton biomass and barium incorporation into P. magellanicus shells. Indeed, the occurrence of this bloom, in May 2015, seems to be consistent with the starting of $P$. magellanicus annual growth from other Canadian regions (Chute et al. 2012; Kleinman et al., 1996). Elevated levels of suspended barite $\left(\mathrm{BaSO}_{4}\right)$ have been suggested to be linked with oceanic diatoms primary productivity (Dehairs et al., 1991). Most of the barium released by diatoms after a bloom is labile and only a minor fraction eventually forms barite crystals (Ganeshram et al., 2003). Therefore, if labile barium, either in phytoplankton or released into the dissolved phase, was the cause of the $\mathrm{Ba} / \mathrm{Ca}$ peaks, these peaks should form near the end of the bloom or very shortly thereafter (Gillikin et al., 2008). Considering the absence of daily growth lines in $P$. magellanicus, we cannot conclude about chlorophyll $a$ and $\mathrm{Ba} / \mathrm{Ca}$ peaks timing. Finally, the two $\mathrm{Ba} / \mathrm{Ca}$ profiles exhibited a double peak, with a first large amplitude one and a smaller second peak. This observation has also been made in P. maximus $\mathrm{Ba} / \mathrm{Ca}$ profiles (Gillikin et al., 2008). One explanation for this double peak proposed in this study is based on Ganeshram et al. (2003). They found that barite formation can take several weeks to reach 
its maximum after the beginning of phytoplankton decay. Barite may be formed at the sediment surface and be ingested by $P$. magellanicus several weeks after the phytoplankton bloom ends.

These observations on $\mathrm{Ba} / \mathrm{Ca}$ incorporation in $\mathrm{P}$. magellanicus shell from SPM imply a real need for complementary information related to local $P$. magellanicus growth dynamics and physiology. It would also be crucial to get insights about the nature and the quantity of benthic and pelagic primary production over the year and along a bathymetric gradient.

\subsection{Magnesium}

In bivalve shells, the relationship between seawater temperature and $\mathrm{Mg} / \mathrm{Ca}$ ratio is still subject to controversy. Some authors proposed that $\mathrm{Mg} / \mathrm{Ca}$ ratios can be used to record water temperature (e.g., Bougeois et al., 2014; Lazareth et al., 2003; Mouchi et al., 2013; Surge and Lohmann, 2008; Ullmann et al., 2013), while there are many reports of strong vital effects in bivalve shells for this element (e.g., Elliot et al., 2009; Lorrain et al., 2005, Wanamaker et al., 2008,). In this study, we can hardly discuss the importance of vital effects on trace elements incorporation into P. magellanicus shell. Indeed, our analyses were only carried out on one year of growth (ontogenetic and calendar) and one individual per site. The only thing we can say about physiological control of $\mathrm{Mg}$ incorporation in P. magellanicus shell is based on $\mathrm{Mg} / \mathrm{Ca}$ level. In this study, the mean $\mathrm{Mg} / \mathrm{Ca}$ ratio ( $\sim 500 \mu \mathrm{g} \cdot \mathrm{g}^{-1}$ corresponding to $\sim 2 \mathrm{mmol} \mathrm{mol}^{-1}$ ) of the calcitic outer shell layer of $P$. magellanicus corresponds to a low value compared to other calcitic mollusc shells (Lazareth et al., 2007 and references therein). Given the absence of sclerochemical studies about trace element incorporation in $P$. magellanicus shells, we can only try to explain these low $\mathrm{Mg}$ concentrations relying on studies based on other calcitic bivalves with low $\mathrm{Mg} / \mathrm{Ca}$ concentrations. For example, Lorens and Bender (1977) suggested that Mytilus edulis biologically regulates the amount of $\mathrm{Mg}$ entering the extrapallial fluid to produce low-Mg calcite. Perhaps a similar process occurs in P. magellanicus, suggesting a physiological control of $\mathrm{Mg}$ incorporation that could obscure $\mathrm{Mg} / \mathrm{Ca}$ and seawater temperature relationship. This confirms the need for additional investigations on biomineralization, e.g. through experiments in controlled environments, in order to better understand trace elements incorporation in P. magellanicus shell. However, 
the shape of the two $\mathrm{Mg} / \mathrm{Ca}$ profiles tend to highlight kind of a temperature control on magnesium incorporation in our shells. At $10 \mathrm{~m}$, the sinusoidal pattern of $\mathrm{Mg} / \mathrm{Ca}$ ratio may reflect the seasonal seawater temperature annual cycle at $10 \mathrm{~m}$ depth. While at $30 \mathrm{~m}$, the $\mathrm{Mg} / \mathrm{Ca}$ profile presents a relatively flat baseline with high-frequency variations, which could mirror the seawater seasonal temperature trend, namely showing low seasonal amplitudes with high-frequency variations (Lazure et al., 2018). Other studies also point to the nonsystematic relationship between $\mathrm{Mg} / \mathrm{Ca}$ ratio and SST. From a one year study of $\mathrm{M}$. edulis growth, Vander Putten et al. (2000) observed a positive correlation between $\mathrm{Mg} / \mathrm{Ca}$ and SST only during spring. Small-scale variations in Mg concentrations in $\mathrm{M}$. edulis calcite have also been shown to derive from $\mathrm{Mg}$ being concentrated along the margins of calcite prisms (Rosenberg et al., 2001). Indeed, the absence of interannual growth lines on the $P$. magellanicus shell is problematic to convert analysed distances in time. That is why enhance our knowledge on P. magellanicus growth dynamics along this bathymetric gradient in SPM would help us decipher physiological and environmental effects on trace element incorporation in P. magellanicus shell calcite. In addition, the lack of high frequency environmental data limits our ability to fully interpret our results and confirms the interest to set up a high frequency observatory along this bathymetric gradient.

\subsection{Uranium}

360

In our study, $\mathrm{U} / \mathrm{Ca}$ and $\mathrm{Mg} / \mathrm{Ca}$ profiles show a strong positive correlation in shells collected at $30 \mathrm{~m}(\mathrm{~N}=3135, \mathrm{r}=0.62, p<0.001)$ (Fig. 10). However, this is not the case for the shallowest shells for which no significant correlation could be found. These results suggest that (i) environmental uranium availability for $P$. magellanicus are not the same between the two sites and/or (ii) that physiological differences between P. magellanicus from $10 \mathrm{~m}$ and $30 \mathrm{~m}$ sites could lead to differential incorporation of uranium in shells.

Since (i) we do not have information about $P$. magellanicus physiological differences between these two depths, and (ii) only few studies previously investigated $U / C a$ ratio as a potential paleo environmental proxy in bivalve shells (Frieder et al., 2014; Gillikin and Dehairs, 2012; Zhao et al., 2018), it seems difficult to draw conclusions about the kind of processes influencing uranium incorporation in P. magellanicus shells. 
To our knowledge, U/Ca ratio as a paleo environmental proxy has been studied for the first

372 time in mollusc shell by Gillikin and Dehairs (2012). In this study the authors tried to 373 investigate U/Ca in Saxidomus gigantea shell as a potential acidification proxy and concluded 374 that U/Ca may not reflect environmental variability and did not function as a paleo-pH proxy. More recently, Zhao et al. (2018) also found virtually unchanged U/Ca values in Mya arenaria shells with increasing seawater $p \mathrm{CO}_{2}$ up to $2900 \mu$ atm. However, in the same study the authors found a significant increase in $\mathrm{U} / \mathrm{Ca}$ ratio in shells with the increase in seawater $p \mathrm{CO}_{2}$ at $6600 \mu \mathrm{atm}$. These findings reveal the existence of certain compensatory mechanisms by which this species may partially mitigate the impact of high environmental $p \mathrm{CO}_{2}$ on shell formation through modifying the calcifying fluid chemistry to maintain its $\mathrm{pH}$ homeostasis (Zhao et al., 2018). These conclusions lead us to consider P. magellanicus physiological responses induced by the repeated thermal variations occurring at the $31 \mathrm{~m}$ site and their impact on the calcifying fluid $\mathrm{pH}$ of this species. Considering our study purpose and resolution, it seems difficult to conclude about $\mathrm{U} / \mathrm{Ca}$ as a potential acidification proxy in $P$. magellanicus shell, especially as we do not have $\mathrm{pH}$ measurements on our study sites. Uranium-to-calcium ratios have also been suggested as a proxy for temperature in shallow water corals (e.g., Min et al., 1995; Shen and Dunbar, 1995) and in planktonic foraminiferal carbonates (e.g., Yu et al., 2008). In our study, the positive correlation between U/Ca and $\mathrm{Mg} / \mathrm{Ca}$ profiles in the shell collected at $30 \mathrm{~m}$ would support this hypothesis. However, this correlation does not hold anymore at $10 \mathrm{~m}$, suggesting that variations in uranium bioavailability differs between our two sites. Indeed, microorganisms have the ability to adsorb radionuclides/metals through extracellular binding involving physical adsorption, ion exchange, complexation and precipitation (Acharya et al., 2009). They also sequester the metal ions by passive/active transport to the interior of the cell, followed by its accumulation. Microbial cells have been shown to reduce, oxidize, adsorb, accumulate and precipitate uranium (Fredrickson et al., 1999; Macaskie et al., 2000). So differences in microbial communities between the two sites, related to the nature of the habitat or to depth, could lead to changes in environmental uranium availability and finally to shell $\mathrm{U} / \mathrm{Ca}$ ratios. 


\section{Conclusion}

401

402

403

404

405

406

407

408

409

410

411

412

413

414

415

416

417

Our novel approach using ultra-high resolution fs-LA-ICPMS enables trace element analyses in bivalve shells with a $10-\mu \mathrm{m}$ resolution. This study gave us first insights about $P$. magellanicus ability to record high-frequency environmental variations within is shell at a sub-hourly scale.

From an analytical point of view, it would be interesting to continue this study by applying this new analytical technique to more individuals. This would allow us to discuss about interindividual variability within those two sites. Moreover, combining this approach with nanoSIMS $\delta^{18} \mathrm{O}$ measurements (temperature proxy) would help us to get insights about the temperature control of $\mathrm{Mg}$ and $\mathrm{U}$ incorporation in shells.

In term of data interpretation, these results also confirm a real need for complementary information. Some of them should be related to $P$. magellanicus intra-annual growth dynamics. Indeed, in this study the absence of visible intra-annual growth lines visible on $P$. magellanicus shells hindered the temporal alignment of our microchemical data. Others must concern P. magellanicus physiological responses and their impacts on the calcifying fluid chemistry of this species. All these additional studies will require multiple high frequency environmental data continuously recorded at an individual scale within those two sites.

\section{Acknowledgements}

First, we thank the LEMAR (UMR 6539) Secretariat team (Anne-Sophie Podeur, Geneviève Cohat, and Yves Larsonneur) for their invaluable assistance during the administrative preparation of the analytical trip associated with this work in Pau. We also thank Gaëlle Barbotin for her help during fsLA-ICPMS measurements in Pau. This work was supported by the EC2CO program MATISSE of the CNRS INSU, the Cluster of Excellence LabexMER, and the LIA BeBEST CNRS INEE. This research was carried out as part of the Ph.D. thesis of Pierre Poitevin for the University of Western Brittany with a French Ministry of Higher Education and Research grant. This manuscript greatly benefited from very useful comments made by the reviewers.

\section{References}

Acharya C, Joseph D, Apte SK (2009) Uranium sequestration by a marine cyanobacterium Synechococcus elongatus strain BDU/75042. Bioressource Technology, 100, 2176-2181. 
Ballesta-Artero I, Witbaard R, Carroll ML, Van der Meer J (2017) Environmental factors

431

432

433 regulating gaping activity of the bivalve Arctica islandica in Northern Norway. Marine Biology, 164 (5), 116.

Barats A, Amouroux D, Pecheyran C, Chauvaud L, Donard OFX (2007) High-Frequency Archives of Manganese Inputs To Coastal Waters (Bay of Seine, France) Resolved by the LA ICPMS Analysis of Calcitic Growth Layers along Scallop Shells (Pecten maximus). Environmental Science \& Technology, 42 (1), 86-92.

Bougeois L, de Rafélis M, Reichart GJ, de Nooijer LJ, Nicollin F, Dupont-Nivet G (2014) A high resolution study of trace elements and stable isotopes in oyster shells to estimate Central Asian Middle Eocene seasonality. Chemical Geology, 363, 200-212.

Butler PG, Richardson CA, Scourse JD, et al. (2010) Marine climate in the Irish Sea: analysis of a 489-year marine master chronology derived from growth increments in the shell of the clam Arctica islandica. Quaternary Science Reviews, 29, 1614-1632.

Carré M, Bentaleb I, Bruguier O, Ordinola E, Barrett NT, Fontugne M (2006) Calcification rate influence on trace element concentrations in aragonitic bivalve shells: Evidences and mechanisms. Geochimica et Cosmochimica Acta, 70, 4906-4920.

Chauvaud L, Thouzeau G, Paulet YM (1998) Effects of environmental factors on the daily growth rate, Journal of Experimental Marine Biology and Ecology, 227, 83-111.

Chung GS, Swart PK (1990) The concentration of uranium in freshwater vadose and phreatic cements in a Holocene ooid cay; a method of identifying ancient water tables. Journal of Sedimentary Research, 60, 735-746.

Chute AS, Wainright SC, Hart DR (2012) Timing of shell ring formation and patterns of shell growth in the sea scallop Placopecten magellanicus based on stable oxygen isotopes. Journal of Shellfish Research, 31, 649- 662.

Coffey M, Dehairs F, Collette O, Luther G, Church T, Jickells T (1997) The behaviour of dissolved barium in estuaries. Estuarine, Coastal and Shelf Science, 45, 113-121.

Dehairs F, Stroobants N., Goeyens L (1991) Suspended barite as a tracer of biological activity in the Southern Ocean. Marine Chemistry, 35, 399-410. 
Elliot M, Welsh K, Chilcott C, McCulloch M, Chappell J, Ayling B (2009) Profiles of trace elements and stable isotopes derived from giant long-lived Tridacna gigas bivalves: Potential applications in paleoclimate studies. Palaeogeography, Palaeoclimatology, Palaeoecology, 280, 132-142.

Fredrickson JK, Kostandarithes HM, Li SW, Plymale AE, Daly MJ (1999) Reduction of Fe(III), $\mathrm{Cr}(\mathrm{VI}), \mathrm{U}(\mathrm{VI})$ and $\mathrm{Te}(\mathrm{VII})$ by Deinococcus radiodurans R1. Applied Environmental Microbiology, 66, 2006-2011.

Freitas PS, Clarke L, Kennedy H, Richardson CA (2008) Inter- and intra-specimen variability masks reliable temperature control on shell $\mathrm{Mg} / \mathrm{Ca}$ ratios in laboratory- and field-cultured Mytilus edulis and Pecten maximus (bivalvia). Biogeosciences, 5, 1245-1258.

Freitas PS, Clarke L, Kennedy H, Richardson CA (2009). Ion microprobe assessment of the heterogeneity of $\mathrm{Mg} / \mathrm{Ca}, \mathrm{Sr} / \mathrm{Ca}$ and $\mathrm{Mn} / \mathrm{Ca}$ ratios in Pecten maximus and Mytilus edulis (bivalvia) shell calcite precipitated at constant temperature. Biogeosciences, 6, 1209-1227.

Freitas PS, Clarke LJ, Kennedy H, Richardson CA (2016) Manganese in the shell of the bivalve Mytilus edulis: Seawater Mn or physiological control? Geochimica et Cosmochimica Acta, 194, 266-278.

Frieder CA, Gonzalez JP, Levin LA (2014) Uranium in Larval Shells As a Barometer of Molluscan Ocean Acidification Exposure. Environmental Science \& Technology, 48 (11), 64016408.Ganeshram RS, Francois R, Commeau J, Brown-Leger SL (2003) An experimental investigation of barite formation in seawater. Geochimica et Cosmochimica Acta, 67, 25992605.

Gillikin D, Dehairs F, Lorrain A, Steenmans D, Baeyens W, Andre L (2006) Barium uptake into the shells of the common mussel (Mytilus edulis) and the potential for estuarine paleochemistry reconstruction. Geochimica et Cosmochimica Acta, 70, 395-407.

Gillikin D, Lorrain A, Paulet YM, Andre L, Dehairs F (2008) Synchronous barium peaks in highresolution profiles of calcite and aragonite marine bivalve shells. Geo-Marine Letters, 28, 351-358.

Gillikin D, Dehairs F (2012) Uranium in aragonitic marine bivalve shells, Palaeogeography, Palaeoclimatology, Palaeoecology, 373, doi: 10.1016/j.palaeo.2012.02.028. 
Kitano Y, Oomori T (1971) The coprecipitation of uranium with calcium carbonate. Journal of the Oceanographic Society of. Japan, 27, 34-42.

489

490

491

492

493

494

495

496

497

498

499

500

501

502

503

504

505

506

507

508

509

510

511

512

Klein R, Lohmann K, Thayer C (1996) Sr/Ca and C-13/C-12 ratios in skeletal calcite of Mytilus trossulus: Covariation with metabolic rate, salinity, and carbon isotopic composition of seawater. Geochimica et Cosmochimica Acta, 60, 4207-4221.

Kleinman S, Hatcher BG, Scheibling RE, Taylor LH, Hennigar AW (1996) Shell and tissue growth of juvenile sea scallops (Placopecten magellanicus) in suspended and bottom culture in Lunenburg Bay, Nova Scotia. Aquaculture, 142, 75-97.

Langmuir D (1978) Uranium mineral-solution equilibria. Geochimica et Cosmochimica Acta, 42, 547-569.

Lazareth CE, Vander Putten E, André L, Dehairs F (2003) High-resolution trace element profiles in shells of the mangrove bivalve Isognomon ephippium: a record of environmental spatio-temporal variations? Estuarine, Coastal and Shelf Science, 57, 1103-1114.

Lazareth CE, Guzman N, Poitrasson F, Candaudap F, Ortlieb L (2007) Nyctemeral variations of magnesium intake in the calcitic layer of a Chilean mollusk shell (Concholepas concholepas, Gastropoda), Geochimica et Cosmochimica Acta, 71, 5369-5383.

Lazareth CE, Le Cornec F, Candaudap F, Freydier R (2013) Trace element heterogeneity along isochronous growth layers in bivalve shell: Consequences for environmental reconstruction. Palaeogeography, Palaeoclimatology, Palaeoecology, 373, 39-49.

Lazure P., Le Cann B., Bezaud M. (2018) Large diurnal bottom temperature oscillations around the Saint Pierre and Miquelon archipelago. Scientific Reports, 8, Article number: 13882.

Lorens R, Bender M (1977) Physiological Exclusion of Magnesium from Mytilus edulis Calcite. Nature, 269, 793-794.

Lorrain A, Gillikin D, Paulet YM, Chauvaud L, Le Mercier A, Navez J, André L (2005) Strong kinetic effects on Sr/Ca ratios in the calcitic bivalve Pecten maximus. Geology, 33 (12), 965968. 
Macaskie LE, Bonthrone KM, Yong P, Goddard D (2000) Enzymatically-mediated bioprecipitation of uranium by a Citrobacter sp.: a concerted role for extracellular lipopolysaccharides and associated phosphatase in biomineral formation. Microbiology, 146, 1855-1867.

Marali S, Schöne BR (2015) Oceanographic control on shell growth of Arctica islandica (Bivalvia) in surface waters of Northeast Iceland-implications for paleoclimate reconstructions. Palaeogeography, Palaeoclimatology, Palaeoecology, 420, 138-149.

Min GR, Edwards RL, Taylor FW, Recy J, Gallup CD, Beck JW (1995) Annual cycles of U/Ca in coral skeletons and U/Ca thermometry. Geochimica et Cosmochimica Acta, 59, 2025-2042.

Mouchi V, de Rafélis M, Lartaud F, Fialin M, Verrecchia E (2013) Chemical labelling of oyster shells used for time-calibrated high-resolution $\mathrm{Mg} / \mathrm{Ca}$ ratios: a tool for estimation of past seasonal temperature variations. Palaeogeography. Palaeoclimatology. Palaeoecology, 373, 66-74.

Poitevin P, Thébault J, Schöne BR, Jolivet A, Lazure P, Chauvaud L (2018) Ligament, hinge, and shell cross-sections of the Atlantic surfclam (Spisula solidissima): Promising marine environmental archives in NE North America. Plos One, 13(6), e0199212.

Rosenberg GD, Hughes WW, Parker DL, Ray BD (2001) The geometry of bivalve shell chemistry and mantle metabolism, American Malacological Bulletin, 16, 251-261.

Schöne BR, Radermacher P, Zhang Z, Jacob DE (2013) Crystal fabrics and element impurities ( $\mathrm{Sr} / \mathrm{Ca}, \mathrm{Mg} / \mathrm{Ca}$, and $\mathrm{Ba} / \mathrm{Ca}$ ) in shells of Arctica islandica-Implications for paleoclimate reconstructions. Palaeogeography, Palaeoclimatology, Palaeoecology, 373, 50-59.

Shen GT, Dunbar RB (1995) Environmental controls on uranium in reef corals. Geochimica et Cosmochimica Acta, 59, 2009-2024

\section{Shirai K, Schöne BR, Miyaji T, Radarmacher P, Krause RA Jr., Tanabe K (2014) Assessment of} the mechanism of elemental incorporation into bivalve shells (Arctica is/andica) based on elemental distribution at the microstructural scale. Geochimica et Cosmochimica Acta, 126, 307-320. 
541

542

543

544

545

546

547

548

549

550

551

552

553

554

555

556

557

558

559

560

561

562

563

564

565

566

567

Stecher HA, Krantz DE, Lord CJ, Luther GW, Bock KW (1996) Profiles of strontium and barium in Mercenaria mercenaria and Spisula solidissima shells. Geochimica et Cosmochimica Acta, 60 (18), 3445-3456.

Stecher HA, Kogut MB (1999) Rapid Barium removal in the Delaware estuary. Geochimica et Cosmochimica Acta, 63, 1003-10012.

Surge D, Lohmann KC (2008) Evaluating $\mathrm{Mg} / \mathrm{Ca}$ ratios as a temperature proxy in the estuarine oyster, Crassostrea virginica. Journal of Geophysical Research, 113, G02001.

Thébault J, Chauvaud L, L'Helguen S, Clavier J, Barats A, Jacquet S, Pecheyran C, Amouroux D (2009). Barium and molybdenum records in bivalve shells: Geochemical proxies for phytoplankton dynamics in coastal environments? Limnology and Oceanography, 54, 10021014.

Ullmann CV, Böhm F, Rickaby REM, Wiechert U, Korte C (2013). The Giant Pacific Oyster (Crassostrea gigas) as a modern analog for fossil ostreoids: isotopic (Ca, O, C) and elemental (Mg/Ca, Sr/Ca, Mn/Ca) proxies. Geochemistry, Geophysics, Geosystems, 14, 4109-4120.

Vander Putten, E, Dehairs F, Keppens E, Baeyens W (2000) High resolution distribution of trace elements in the calcite shell layer of modern Mytilus edulis: Environmental and biological controls. Geochimica et Cosmochimica Acta, 64, 997-1011.

Wanamaker AD, Kreutz KJ, Wilson T, Borns HW, Introne DS, Feindel S (2008) Experimentally determined $\mathrm{Mg} / \mathrm{Ca}$ and $\mathrm{Sr} / \mathrm{Ca}$ ratios in juvenile bivalve calcite for Mytilus edulis: implications for paleotemperature reconstructions. Geo-Marine Letters, 28, 359-368.

Warter V, Müller W (2017) Daily growth and tidal rhythms in Miocene and modern giant clams revealed via ultra-high resolution LA-ICPMS analysis - A novel methodological approach towards improved sclerochemistry. Palaeogeography, Palaeoclimatology, Palaeoecology, 465, 362-375.

Witbaard R, Duineveld GCA, DeWilde PAWJ (1997) A long-term growth record derived from Arctica islandica (Mollusca, Bivalvia) from the Fladen Ground (northern North Sea). Journal of the Marine Biological Association of the United Kingdom, 77 (3), 801-816. 
$568 \mathrm{Yu} \mathrm{J}$, Elderfield H, Jin Z, Booth L (2008) A strong temperature effect on U/Ca in planktonic 569 foraminiferal carbonates. Geochimica et Cosmochimica Acta, 72, 4988-5000.

570 Zhao L, Milano S, Walliser EO, Schöne BR (2018) Bivalve shell formation in a naturally CO2-

571 enriched habitat: Unraveling the resilience mechanisms from elemental signatures.

572 Chemosphere, 203, 132-138. 


\section{Highlights :}

- A new method to resolve shell elemental composition with a $10 \mu \mathrm{m}$ resolution.

- $\mathrm{Ba} / \mathrm{Ca}$ of Placopecten magellanicus shell seem to be related to phytoplankton dynamic.

- $\mathrm{Mg} / \mathrm{Ca}$ and $\mathrm{U} / \mathrm{Ca}$ of $P$. magellanicus shell seem partially temperature dependent.

- This species might also present a physiological control on $\mathrm{Mg}$ and $\mathrm{U}$ incorporation.

- This method may contribute to a better understanding of ion incorporation in shells. 


\section{Declaration of interests}

$\bigotimes$ The authors declare that they have no known competing financial interests or personal relationships that could have appeared to influence the work reported in this paper.

$\square$ The authors declare the following financial interests/personal relationships which may be considered as potential competing interests: 